Article

\title{
Towards Inclusion in Spanish Higher Education: Understanding the Relationship between Identification and Discrimination
}

\author{
Beatriz Gallego-Noche ${ }^{1, *}$, Cristina Goenechea ${ }^{1}$, Inmaculada Antolínez-Domínguez ${ }^{2}$ \\ and Concepción Valero-Franco ${ }^{3}$ \\ ${ }^{1}$ Department of Didactics, Faculty of Education, University of Cadiz, Spain; E-Mails: beatriz.gallego@uca.es (B.G-N.), \\ cristina.goenechea@uca.es (C.G-P.) \\ 2 Department of Labor Law and Social Security, University of Cadiz, Spain; E-Mail: inmaculada.antolinez@uca.es \\ ${ }^{3}$ Department of Statistics and Operations Research, University of Cadiz, Spain; E-Mail: concepcion.valero@uca.es \\ * Corresponding author
}

Submitted: 25 January 2021 | Accepted: 16 April 2021 | Published: 21 July 2021

\begin{abstract}
It is more and more evident that there is diversity among university students, but this diversity encompasses a wide variety of personal characteristics that, on occasion, may be subject to rejection or discrimination. The feeling of inequality is the result of one stand-alone characteristic or an intersection of many. To widen our knowledge of this diversity and to be able to design actions with an inclusive approach, we have set out to explore the relationship between students' feelings of discrimination, their group identification and their intersections. Participants for the study are selected from protected groups which fall into the following criteria: ethnic minority, illness, migrant minority, disability, linguistic minority, sexual orientation, income, political ideology, gender, age and religion. We will refer to this relationship as the 'discrimination rate.' To fulfil our objective, we have given a questionnaire to a sample of 2,553 students from eight Spanish universities. The results indicate that the characteristics with which they most identify are religion, age, sex and political ideology. However, the highest rate of discrimination is linked to linguistic minority, ideology and migration. Regarding intersectionality, it is worth noting that $16.6 \%$ of students feel discriminated against for more than one characteristic, with the most frequent relationships being the following: (1) ethnic or migrant minorities (2) sexual orientation, sex, being under 30 , leftist ideology, low income, linguistic minority and (3) Christian Catholic, right-wing and upper-class ideology.
\end{abstract}

\section{Keywords}

discrimination; higher education; inclusive education; Spain; university students

\section{Issue}

This article is part of the issue "Inclusive Universities in a Globalized World" edited by Liudvika Leišyte (TU Dortmund, Germany), Rosemary Deem (Royal Holloway, UK) and Charikleia Tzanakou (Oxford Brookes University, UK).

(C) 2021 by the authors; licensee Cogitatio (Lisbon, Portugal). This article is licensed under a Creative Commons Attribution 4.0 International License (CC BY).

\section{Introduction}

The growing democratization of access to higher education brings with it the presence of an increasingly diverse student body. In Spain, the number of university students has doubled in recent decades, from just over 850,000 in the academic year 1985-1986 to over $1,500,000$ today, representing $31 \%$ of the population aged 18-24 (Spanish Ministry of Universities, 2020). However, the debate about diversity in Spanish univer- sities has been going for not even a decade (García-Cano et al., 2021). Decisive in increasing the attention paid by Spanish universities to diversity have been the global and European guidelines which, conscious of the role of universities in the development of democratic and sustainable societies, advocate the design and development of concrete actions to meet student diversity (EHEA Ministerial Conference, 2012; EU, 2015; UNESCO, 1998, 2015). It is evident that there is a need to question and reflect on the role of universities in providing 
adequate responses for the inclusion of traditionally excluded and under-represented groups in the educational space (Bowes et al., 2015; Goenechea et al., 2020; Hurtado \& Ruiz, 2015; Mulcahy et al., 2017). The study by García-Cano et al. (2021) includes several indicators from various sources that outline that Spain still has a long way to go in this respect: (1) the likelihood of graduating after the age of 25 is lower than in other countries in the EU-23 bloc or the OCDE, which is $0.4 \%$ and $1.4 \%$, respectively, (2) those with parents who have not obtained university qualifications and have a low income or economic difficulties are also less likely to complete higher education in Spain and (3) attendance at Spanish universities of students with disabilities is estimated to be lower in relation to populations without any disability ( $1.7 \%$ of all university students). Although no ethnic data are collected in Spain, previous studies (Goenechea et al., 2020) estimate that only $2 \%$ of the Roma population attend university studies.

Following the argument that education must meet social demands, these being understood as the training that students need to satisfy those positions in the job market that support and maintain the system; there is a clearly reductionist interpretation of what society is. This, subsequently, reduces educational institutions to exclusive providers of employability for companies (Díez Gutiérrez, 2011; Nussbaum, 2010). This not only relegates the responsibility that university institutions have to develop policies and practices which address vulnerable groups to second place but also their contributions to improving their social and environmental impact.

Accompanying this, deficit thinking (Banks, 2009), which holds students responsible for accessing university studies without having the sufficient skills or knowledge, forgets that there are many structures that prevent students belonging to discriminated groups from succeeding in their studies. This is even more so when the characteristics that justify their disability are intersected (Barnett \& Felten, 2016; Gallego-Noche, 2019). The success of disadvantaged university students requires the consideration of an inclusive approach to diversity which is based on social justice, not exclusively on the assessment of outcomes related to employability or graduation rates.

Therefore, there are three elements that we consider fundamental in the study of student discrimination at the university:

- Inclusive attention to diversity

- Intersectional analysis of discrimination

- Social justice, understood from a multidimensional perspective (Fraser, 1997, 2011, 2012), which makes it possible to approach inclusive actions from a triple perspective: material, cultural, and participatory.

The demand for this social justice is the main argument for taking necessary actions to transform oppressive structures and allow all students, regardless of how they may identify or be identified, to maximize the development of their abilities and to do so in a context of equality. It is centered in this perspective that we place this body of research whose main objective is to investigate the perception of discrimination by sampling Spanish university students according to the most relevant identification groups and their intersections. Our main research questions are: Which groups do university students identify with? To what extent do the members of each group feel discriminated against or not? Is this feeling of discrimination intersectional?

\section{An Inclusive Approach to Diversity in Higher Education, Social Justice, and the Intersection of Inequalities}

\subsection{An Inclusive Approach to Diversity as Social Justice}

A situation of vulnerability for a student can be caused by their age, ethnic origin, gender, economic status, physical characteristics, health status, disability, cultural or political circumstances and any other factor that may present a significant risk of their rights and fundamental freedoms being violated (Hanne \& Mainardi, 2013). Different research projects (Gairín Sallán \& Suárez, 2016; Goenechea et al., 2020; Hanne \& Mainardi, 2013; Mulcahy et al., 2017; Padilla-Carmona et al., 2017) show that a system of economic aids for the inclusion of these students is not sufficient. It is necessary to also create alternative models that contribute to changing the stereotypes and subjectivities created by the hierarchical systems of oppression and inequality, and, to this end, we refer to the contributions of Fraser $(1997,2011$, 2012) and her multidimensional conception of social justice. Using Fraser's model of justice as a theoretical framework offers interesting possibilities for the theoretical construction of an inclusive approach to university education. From this perspective, justice requires social arrangements that allow all people to interact with each other as equals and as free beings.

This involves distinguishing three ways of understanding injustice: material, non-recognition, and social non-participation (Fraser, 1997, 2011). Material injustice is rooted in political and economic structures such as exploitation, economic marginalization, and deprivation from a minimal standard of living. The injustice of non-recognition operates on institutionalized hierarchies of cultural value that deny adequate recognition. This type of injustice does not respond to the struggle for the recognition of cultural identities from hegemonic multiculturalism. Rather, it responds to the demand for equal moral value for all people regardless of their self-assigned or hetero-assigned group. The notion of injustice regarding non-participation refers to the material and cultural limitations imposed on having equality in political participation and representation. These types of injustices should not be understood as 
separate realities, but as planes that generate multiplicative effects.

Moreover, it is fundamental to discard the apolitical narratives that have made people naturalize differences and their unequal value. The discourse of diversity, which is politically and ideologically related to the discourse of liberal multiculturalism and its economistic vision (Ahmed, 2007, 2012), celebrates differentiation in a society that is understood as a multicultural kaleidoscope where differences coexist in harmony. These differences are understood in isolation and homogenize people who are part of the same group. No further could this be from the reality in which differences are seen as inequalities, their intersections are treated with complex oppression and the experiences of each person are singular and, on too many occasions, dramatic (Gallego-Noche, 2019).

On the contrary, the critical perspective considers heterogeneity to be a constitutive part of the human being and finds that the social, political, and economic structures, which give a subordinate value to certain groups, are the cause of the oppression and inequality that provoke social disadvantage. It is therefore the responsibility of institutions to act according to the values of equity and social justice (Rawls, 1999).

This approach to injustice, therefore, defends the need to combine policies of redistribution, which not only encompass the equitable distribution of resources but also include the deconstruction of economic structures that generate inequality, with policies of recognition. This is to be done through radical strategies that allow the construction of the alternative discourses that are reflected in the organization of political, economic, social, and cultural structures (which are racist, androcentric, heteropatriarchal, adult-centered and colonial).

Establishing interpretative schemes in the community supposes doing things in a way that makes university education be based on critical questioning, deliberative democratic participation, and equal decision making. These schemes would allow for the understanding that situations of inequity are not unfortunate, but rather unjust and are acts of domination. They would also allow people not to blame themselves for their situation, but to channel their legitimate indignation towards social transformation. To this end, it is necessary that inclusive university policies and practices integrate a triple perspective: equality of economic resources (material justice), critical questioning of unequal value attributions (recognition justice) and deliberative democratic participation (participatory justice).

\subsection{The Intersection of Oppression}

Since the first contributions from Crenshaw (1989), Collins and Bilge (2016) have situated the antecedents of the concept of intersectionality in the conjunction of different social movements during the $60 \mathrm{~s}$ and 70s that acted to denounce structural inequality and the consequences it had on the lives of people from oppressed groups. Collins $(2015$, p. 2) defines it as "the critical insight that race, class, gender, sexuality, ethnicity, nation, ability, and age operate not as unitary, mutually exclusive entities, but as reciprocally constructing phenomena that in turn shape complex social inequalities."

The concept of intersectionality has become a springboard for the analysis of power relations that produce inequalities and oppression and has given way for the need for critical inquiry that questions educational practices and political interventions that are incapable of responding to non-hegemonic realities (Romero \& Montenegro, 2018).

We believe, supported by Fraser (1997, 2011, 2012), that in addition to the need to address material deprivation (redistributive justice) and how it affects postcompulsory education possibilities, attention must also be paid to how cultural patterns of unequal value (recognition justice) and lack of participation hinder social and educational equity. Fraser's conception of social justice establishes its dimensions in an intersected way, just as the social inequalities that generate oppression are intersected. These inequalities are not accumulative but rather are mutually constitutive and the ways of experiencing them are multiple. It is in the ways of experiencing them, or rather, perceiving them, that this article puts its emphasis.

Whilst it is not possible to say that said oppressions accumulate and operate in the same way in each and every case, this can be said to be true for the omnipresence of the definition of power and the oppressive forms with which it is executed. West and Fenstermarker (2010) recognize the existence of multiple forms of oppression which are derived from social, cultural, and political categorizations whose particular intersections depend on the concrete context where they take place and the way these are experienced by each person.

Thus, intersectional analysis allows us to challenge the ways in which structures of domination interact and intersect to influence the specific identity experiences of people from minority groups (Harris \& Patton, 2019; Nash, 2008).

These hierarchical forms of social organization, which are socio-historical systems and mutually constitutive structures of inequality, are (1) social, cultural, and psychological systems of homogenizing, segregationist imposition, obedience, and undervaluation, (2) economic class systems and (3) political systems in which there is no true participatory democracy. These all impede equality and social justice (Bookchin, 2006; Gallego-Noche, 2019; Harris \& Patton, 2019).

In this way, the inclusive approach that we maintain based on social justice and contemplating the intersectionality of oppression, allows us to further understand the information gained from the students' selfidentification with certain political, social, and cultural categories and the perception that they themselves have 
of the experience of discrimination that their membership entails.

\section{Methodology}

One of the specific objectives of the research project this article is based upon (supported by the Spanish Ministry of Science, Innovation, and Universities) is to explore the perception of discrimination from a sample of university students according to the most relevant identification groups and their intersections.

Both the need to understand the discourses of the agents involved in the reality we intend to investigate and the challenges put to those structures which generate oppression, respond to the notion of inclusive and intersectional research (Collins, 2015; Lall, 2011; Museus \& Griffin, 2011; Nind, 2017). We intend to generate knowledge from the voices of the community, which will contribute to the unveiling of the oppressive and unequal structures that operate in higher education and will transform them into spaces of equality and social justice.

In order to understand the students' perspective, semi-structured interviews, discussion groups, and an ad hoc questionnaire have been developed (mixed method). This research is limited to the information provided by the questionnaire and seeks to respond to the knowledge regarding students' self-identification with a protected group and the feeling of discrimination they experience. The research also addresses the intersection relationship between the characteristics that constitute a diverse identity but for which students feel discriminated against:

In reality, when asked "who are you?" most students, faculty, and administrators in higher education would not respond with a single identity. Rather, an individual's sense of self can be based on many groups with which he or she identifies, and people can be defined simultaneously by their race, ethnicity, class, gender, sexuality, religion, and other aspects of their identities. (Museus \& Griffin, 2011, p. 7)

Firstly, we validated the content of the questionnaire using inter-rater reliability (four people with expertise in the conceptual area of diversity care and 1 person with experience in instrument design) to which both a content validity coefficient (CVC) and a content validity index (CVI) analysis were applied through the SPSS program (v22). Based on the results obtained in both analyses (CVC and CVI), the items with the highest valuesbetween $0.95-1.00$ in the criteria of relevance, comprehension and ambiguity-were selected, and the experts' contributions were included. Later, we carried out a pilot test with 51 students which led to the final version of the questionnaire. The questionnaire was configured around the following dimensions:
- Socio-demographic variables (10 items)

- Beliefs, attitudes, and practices which focus on diversity in the university space (24 items)

- Ideological attitudes (20 items)

- Personality measure (24 items)

The items in the first two dimensions were created by the UCA research team reviewing the work of Lombardi et al. (2016). The items from the final two dimensions were selected from the proposal by Álvarez et al. (2016), which includes several related validated instruments. The theoretical dimensions and item design were established. The items formulated to identify and explore the feeling of discrimination caused because of a student's membership in a group are based on the European Directives on non-discrimination, the European Convention on Human Rights and Fundamental Freedoms (ECHR), and the Charter of Fundamental Rights of the European Union (CFR). This resulted in the establishment of the specific groups being included in Table 1.

Table 1. Diversity of identification groups.

\begin{tabular}{l}
\hline Protected groups \\
\hline Ethnic minority \\
Migrant minority \\
Minority sexual orientation \\
Sex (Gender) \\
Older population group (over 40 years old) \\
Young population group (under 30 years old) \\
Catholic religion collective \\
Collective of another Christian religion \\
Collective of the Muslim religion \\
Jewish religion collective \\
Collective of another minority religion not mentioned \\
above \\
Atheist collective \\
Agnostic collective \\
Collective indifferent to religion \\
Group of members or supporters of a right-wing \\
political party \\
Group of members or supporters of a left-wing political \\
party \\
Minority with a disability \\
Minority with a chronic or infectious disease \\
High-income socio-economic group \\
Low-income socio-economic group \\
Linguistic minority \\
Other \\
\hline
\end{tabular}

The final version of the questionnaire was given to students from eight universities which were selected by the project management for: being a Spanish university; being diverse in size and regional location; and having 
associated faculty be specialized in the subject and be with whom we had worked previously. The questionnaires were sent between May and September 2019. In some universities, permission to send the questionnaires through the official distribution lists was achieved. In others, this was not possible and the questionnaires were subsequently sent through academic officials. In the academic year in which the questionnaire was carried out (2018-2019), the Spanish university system had a total of $1,290,455$ undergraduate students, distributed among 84 universities. The eight participating universities-all public-had a total of 333,408 undergraduate students, representing $25.8 \%$ of the national total. Specifically, and from highest to lowest number of students, the participating universities were: National Distance Education University $(129,074)$, Complutense University of Madrid $(58,305)$, University of Seville $(52,315)$, University of Cadiz $(18,378)$, University of Cordoba $(14,881)$, University of Jaen $(12,474)$, and Pablo de Olavide University $(9,713)$.

Finally, 2,553 students completed the online questionnaire, creating a significant sample of the population (confidence level greater than $95 \%$ and estimation error less than $2 \%$ ). Of the total number of participants, $62.7 \%$ were women and $37.2 \%$ men. Considering the studies carried out, $83.9 \%$ of the respondents were undergraduate students (first level of university studies), $10.3 \%$ corresponded to master's degree students (second level of studies), and the remaining $5.8 \%$ were doctoral students (final level).

The data analysis was done with the help of SPSS version 22, which allowed us to organize, summarize, and analyze the information obtained from the 2,553 participants. Specifically, the data analyses that were carried out are as follows: firstly, we performed a descriptive analysis of the dichotomous variables which referred to the identification of students with a protected group, as well as an analysis of their feeling of discrimination, organized by collective. This allowed us to analyze the impact of each of the groups, establishing the modalities which we found corresponded with the same factor. Secondly, a percentage indicator of the discrimination rate in each of the protected groups was provided. Finally, the analysis of clusters or grouping carried out allowed us to recognize patterns of behavior with respect to the feeling of discrimination, with not only the resulting groups being of interest but also the discriminative or classificatory power derived from them.

\section{Results}

\subsection{Identification with Protected Groups}

In this section, we gather the answers to the question: In which of these groups do you recognize yourself or identify with? The answers to which were chosen from the multiple options from Table 1. Focusing on which of the groups from the questionnaire students identified, we note that 2,221 of the 2,553 students surveyed identify with at least one, that is $87 \%$, of which: $63.26 \%$ are women and $87.16 \%$ are studying a degree in one of the universities. On the other hand, $13 \%$ do not identify with any of the 21 groups mentioned.

It is noteworthy that it is religious belief (or the absence thereof) the factor with which the participating university students most identified. This is above other identification groups such as gender or socio-economic background which could be assumed, a priori, to generate a greater sense of belonging. Thus, $71.23 \%$ of those who identify with a group do so with those related to religion. Among these students were those who consider themselves as atheists and indifferent $131.98 \%$ and $36.29 \%$ ) or as Catholics (28.76\%), with a very small minority $(3 \%)$ corresponding to other religions (Muslim, Jewish, other Christian religion or other minority religion not mentioned above).

The next group to be noted is that of age. $61.9 \%$ of the $57.32 \%$ who identify with age do so because they are over 40 .

We note that only $38.78 \%$ say they identify themselves with the corresponding group in terms of gender, being mostly (83.14\%) women. Specifically, 715 of the 1,595 participating women (44.82\%) and 145 of the 950 men $(15.26 \%)$ marked this response. Therefore, it is a factor that causes a strong feeling of identification for women, but not for men, which may be due to the fact that being a man does not lead to a feeling of identification in an andronormative society.

The next group to be mentioned is political ideology, with which $35.84 \%$ of respondents identify themselves. Specifically, $81.53 \%$ do so with left-wing political beliefs, as opposed to $18.47 \%$ with right-wing political beliefs.

Per capita income ranks fifth as an identification factor, with $25.08 \%$ marking this. $84.02 \%$ of this group marked this group due to low income.

This is followed in descending order by sexual orientation, linguistic minority, disability, migrant minority, illness, and ethnic minority.

Table 2 shows the data in detail. In it, we have grouped some of the identification items into the major factors mentioned (religion, sex, income, political ideology, age). Figure 1 allows us to visualize the situation described.

\subsection{Perception of Discrimination Caused by the Identification with a Protected Group}

Analyzing the feeling of discrimination of those who identify with a group or several is the objective of this section. Specifically, the question asked was: Have you felt personally discriminated against, in the last twelve months, due to...? The same 21 multiple choice answers were offered (see Table 1).

Figure 2 illustrates the results obtained and highlights those groups for which most people feel discriminated against, using the specific data collected in Table 3. 
Table 2. Identification with protected groups.

\begin{tabular}{|c|c|c|c|}
\hline Identification & & Frequency & Percentage \\
\hline \multirow[t]{22}{*}{ Valid } & Sex & 860 & 38.72 \\
\hline & Woman & 715 & 83.14 \\
\hline & Man & 145 & 16.86 \\
\hline & Political ideology & 796 & 35.84 \\
\hline & Left-wing & 649 & 81.53 \\
\hline & Right-wing & 147 & 18.47 \\
\hline & Income & 557 & 25.08 \\
\hline & Low & 468 & 84.02 \\
\hline & High & 89 & 15.97 \\
\hline & Age & 1,273 & 57.32 \\
\hline & $>40$ & 788 & 61.90 \\
\hline & $<30$ & 485 & 38.10 \\
\hline & Sexual orientation & 290 & 13.06 \\
\hline & Linguistic minority & 214 & 9.64 \\
\hline & Migrant minority & 136 & 6.12 \\
\hline & Disability & 152 & 6.84 \\
\hline & Ethnic minority & 71 & 3.20 \\
\hline & With illness & 105 & 4.73 \\
\hline & Religion & 1,582 & 71.23 \\
\hline & Catholic-Christian & 455 & 28.76 \\
\hline & Others & 47 & 2.97 \\
\hline & Atheist & 506 & 31.98 \\
\hline 2,221 & Agnostic-Indifferent & 574 & 36.29 \\
\hline
\end{tabular}

Notes: Created from the information obtained with SPSS.

Of the 2,221 people who identify with at least one group, $44.03 \%$ say they feel discriminated against because of their membership. This supposes a total of 978 students, compared to $55.97 \%$ who do not detail feeling the same. That is, identifying with a group does not necessarily imply a feeling of discrimination because of it. There is also another interpretation: It does not seem necessary to have been discriminated against for

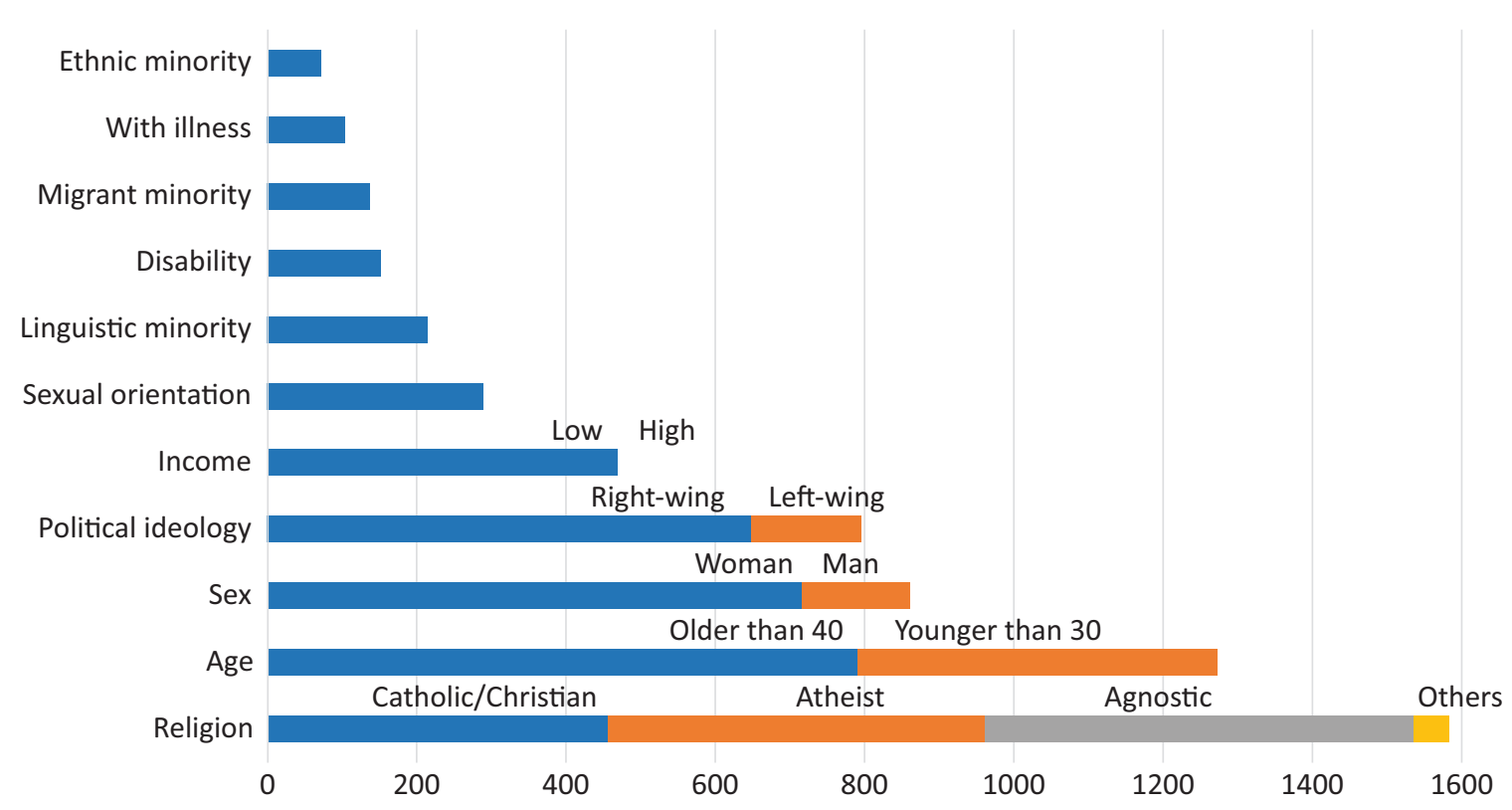

Figure 1. Identification with a group. Created from the data in Table 2. 
Table 3. Feeling of discrimination by collective.

\begin{tabular}{|c|c|c|c|}
\hline Discrimination. & & Frequency & Percentage \\
\hline \multirow[t]{22}{*}{ Valid } & Sex & 346 & 35.38 \\
\hline & Woman & 318 & 91.91 \\
\hline & Man & 28 & 8.09 \\
\hline & Religion & 268 & 27.40 \\
\hline & Catholic-Christian & 158 & 58.96 \\
\hline & Others & 7 & 2.61 \\
\hline & Atheist & 52 & 19.40 \\
\hline & Agnostic-Indifferent & 51 & 19.03 \\
\hline & Political ideology & 233 & 24.54 \\
\hline & Left-wing & 150 & 64.37 \\
\hline & Right-wing & 83 & 5.63 \\
\hline & Age & 221 & 22.60 \\
\hline & $>40$ & 111 & 50.23 \\
\hline & $<30$ & 110 & 49.77 \\
\hline & Income & 180 & 18.4 \\
\hline & Low & 150 & 83.33 \\
\hline & High & 30 & 16.67 \\
\hline & Linguistic minority & 132 & 13.50 \\
\hline & Sexual orientation & 108 & 11.04 \\
\hline & Migrant minority & 59 & 6.03 \\
\hline & Disability & 50 & 5.11 \\
\hline & Ethnic minority & 25 & 2.56 \\
\hline 978 & With illness & 22 & 2.25 \\
\hline
\end{tabular}

Note: Created from the information obtained with SPSS.

belonging to a group in order to identify with it and, therefore, there is not a question of there being reactive identities forming as a result of negative experiences.

Whilst among the identification groups religion was the one with the most response, in terms of discrimi- nation the cause that appears in our analysis with the most pertinence is gender: $35.38 \%$ of the participants feel discriminated against because of their gender, of which $91.91 \%$ are women, something that, although may be expected, is not without its significance. Of the

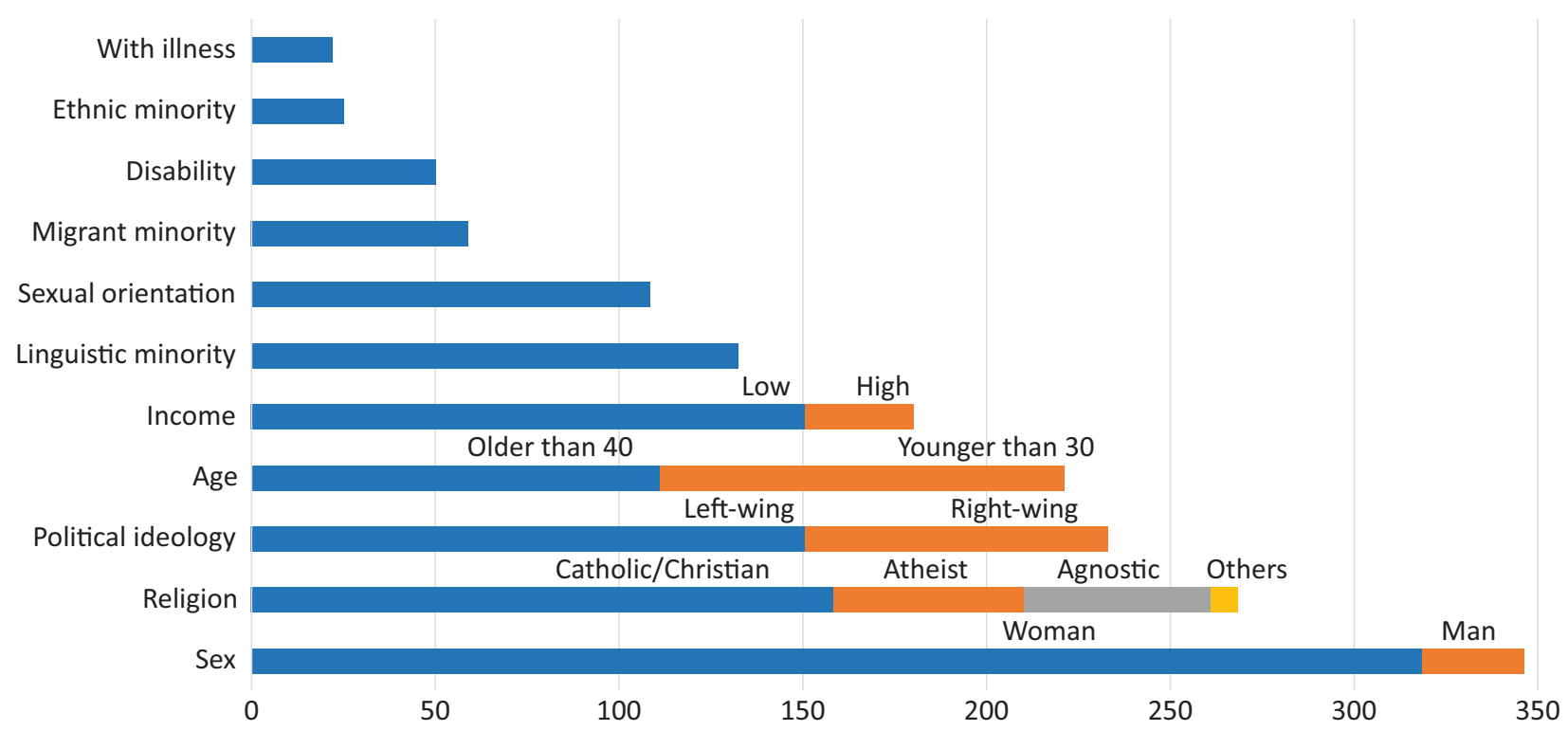

Figure 2. Discrimination. Created from the data in Table 3. 
1,595 women participants, 715 identify with the gender group and 346 have felt discriminated against in the last 12 months for being women.

The second reason why university students feel discriminated against is because of their religious beliefs or lack thereof $(27.4 \%)$; clearly standing out within this category are those who have felt discriminated against because they are Catholics/Christians (58.96\%).

The next factors that cause a feeling of discrimination are the groups regarding a student having a defined political ideology, having a low per capita income and being over 40 years old, followed by belonging to a linguistic minority and having a specific sexual orientation.

In this item, an open space in which students could specify their belonging to another group for which they felt discriminated against was offered. Among the particularly diverse responses, those which stand out refer to: being a mother, being unemployed, having high intellectual capacities, physical appearance, and living in a rural environment.

\subsection{Discrimination Rate}

We are interested in knowing, in addition to the number of people who identify with one or more protected groups, to what extent this membership is or is not accompanied by a perception of discrimination. To do this, we define the discrimination rate as the percentage of people discriminated against with respect to those who identified with the group (discrimination rate $=100 \times$ no. of people discriminated against in a group/no. of people identified with the group). The data are shown in Table 4.

Table 4. Discrimination rate.

\begin{tabular}{lc}
\hline Discrimination & Discrimination rate (\%) \\
\hline Linguistic minority & 61.68 \\
Right-wing ideology & 56.46 \\
Migrant minority & 43.38 \\
Sex & 40.23 \\
Sexual orientation & 37.24 \\
Ethnic minority & 35.21 \\
Being Catholic/Christian & 34.73 \\
High income & 33.71 \\
Disability & 32.89 \\
Low income & 32.05 \\
Left-wing ideology & 24.19 \\
Older than 40 & 22.89 \\
With illness & 20.95 \\
Other religions & 14.89 \\
Older than 30 & 13.96 \\
Atheist & 10.28 \\
Agnostic & 8.89 \\
\hline
\end{tabular}

Note: Created from the information obtained with SPSS.
The factors that result in the highest rate of discrimination are, in this order, belonging to a linguistic minority, having right-wing ideology, being a migrant, and gender. As the group discriminated for being a linguistic minority is the one with the highest rate of discrimination and considering that the University of Valencia is part of the study and has its own dialect, we have calculated the rate separately for those students (63.2\%), although the difference is very little from the rate for the rest of the participants (64\%). Therefore, we conclude that it does not have a particular influence on the rate, although it does on the number of individuals to be considered.

The discrimination rate allows us to understand the strength of an identification factor as a generator of a feeling of discrimination, regardless of the size of that group. Regarding frequency, the group that feels most discriminated against is gender, but this result is due to the fact that it is also the most numerous group. The discrimination rate allows us to re-state the importance of these factors, for example, moving gender to a fourth place in terms of generating a feeling of discrimination.

\subsection{Intersectionality in the Discrimination Rate}

We have focused in this section on looking for relationships between the causes of the feeling of discrimination for those who feel discriminated against in more than one group. A total of 424 students make up this sample, constituting $43.35 \%$ of the 978 who feel discriminated against. This justifies our study into intersectionality, despite the fact that $56.65 \%$ of students attribute their feeling of discrimination to a single cause.

In this section, we look to deepen the knowledge of the intersectionality of categories, analyzing the factors that most often occur in a convergent way and which act as the origin for the feeling of discrimination. In our first analysis, we studied the relationship between variables on a two-by-two basis. The chi-squared test allowed us to detect the association between several pairs of variables (obtaining P-values lower than 0.05) when performing the contrasts. However, this did not allow us to classify the variables into groups that present similarities.

We then resorted to a hierarchical cluster analysis, given the nature of the variables (binary absence/ presence variables). This multivariate statistical classification technique groups variables together to achieve maximum homogeneity in each group and the greatest possible difference between the groups created. Specifically, we made use of the Jaccard Index to obtain the similarities between the variables.

After the attempts to classify with 4-6 clusters or groupings and once we established the groups as isolated elements (Muslim, Jewish and other religions), we proceeded to eliminate the groups from the exploratory study, with the understanding that they did not present similarities with the rest of the groups that we intended to group. 
The cluster analysis of the remaining 18 groups that led to the feeling of discrimination made us consider certain relevant groupings. The dendrogram in Figure 3 shows the groupings derived from the application of a hierarchical clustering algorithm, organizing the groups into subcategories which are then divided into others until the desired level of detail is reached.

Graphically, the dendrogram, which is derived from the Jaccard Coefficient Cluster analysis, is based on a similarity matrix that shows the relationships between the different protected groups considered and the students' feeling of discrimination. The scale on the left shows the similarity index. The limit was established at $23 \%$ similarity. This type of representation allows us to appreciate the relationship between five different groups, highlighting the intersectionality that exists between them:

- Cluster 1: ethnic or migrant minorities

- Cluster 2: sexual orientation, sex, under 30, leftwing political ideology, low per capita income, linguistic minority

- Cluster 3: Catholic-Christian, right-wing political ideology, high income

- Cluster 4: over 40, disabled, with illness

- Cluster 5: atheist, agnostic, indifferent to religion

With the dendrogram, we obtained five groups of factors which together usually produce a feeling of discrimination for the persons who present them. They would therefore be profiles of students who are more likely to feel discriminated against because they belong to several specific groups at the same time. However, our work does not represent the intensity of this feeling (since it works with binary variables and not with a scale) so we cannot say that the feeling of discrimination is greater in those who belong to several groups than in those who only identify with one of them. Yet, it can be assumed that the intersection of discrimination factors is more intense than the experience of only one.

\section{Conclusion}

Both the democratization of access to higher education that universities have experienced, as well as the social recognition of multiple diversities from political movements that have championed the recognition of difference, have led way to an increasingly visible presence of particular groups in the university space. The question of what the university does with this reality has not been the focal subject of this research, but it is certainly a question that we should not lose sight of when addressing inclusion in higher education. In the work presented, and whilst having this question on the horizon, we have looked to evidence the perception of discrimination that a sample of Spanish university students have regarding the groups with which they identify. The analysis carried out, based on the research questions posed at the beginning of the study, reveals several issues of interest.

Firstly, as stated by Museus and Griffin (2011), we consider self-identification to be a completely free

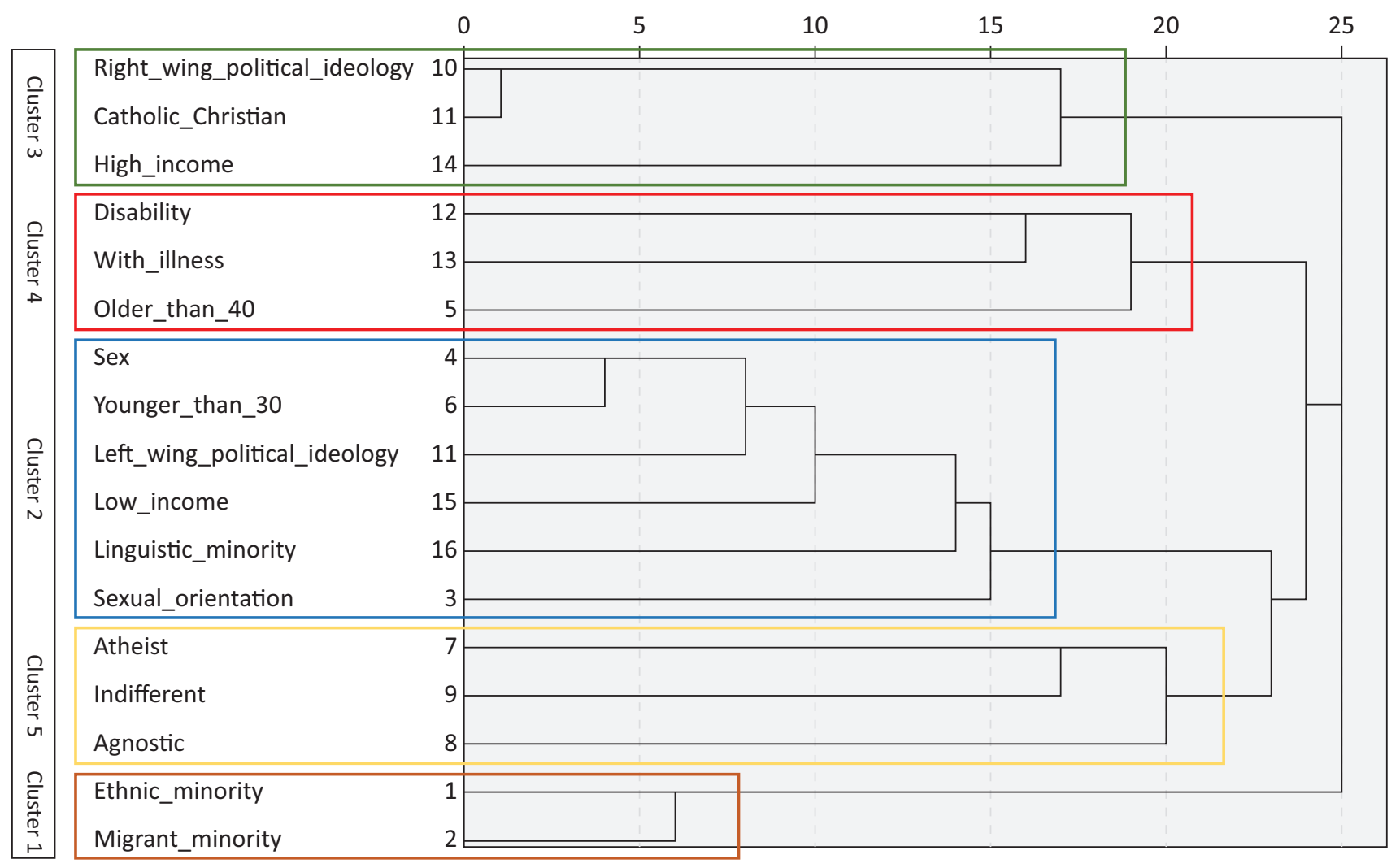

Figure 3. Dendrogram: Feeling of discrimination. 
process, as well as being one that changes over a lifetime However, it should be noted that this work has focused on the categories regarding self-identification as established by the European Directives on non-discrimination, the ECHR and the CFR, as a way of operationalizing the study. We consider, moreover, that such a priori categorization also conditions the educational policies, which sometimes are directed at the group populations to be addressed, thus losing the necessary comprehensive approach in the attention to diversity.

Having clarified this issue, it should be noted that identification with a group considered as vulnerable does not necessarily lead to a feeling of discrimination. Among those who do feel discriminated, belonging to a linguistic minority, having right-wing ideology, being a migrant, and being a woman are the most relevant factors in generating this feeling.

Our study has shown that, beyond the feeling of discrimination by a single category, $43 \%$ of those who feel discriminated against feel this way because of more than one cause. Thus, among the clusters that have emerged, the most relevant is that which establishes an association between ethnic and migratory identity (cluster 1 ). This is logical given that immigration in Spain is still recent. As such, it can be understood that people from ethnic minorities studying at university are (in)migrants, with the exception of the Roma population which is the only national ethnic minority and which, as we stated in the introduction of this study, has an extremely scarce presence at university. This is followed by cluster 2 with a diverse grouping that starts with the essential combination of sex and being under 30, something that may be related to gender identity movements among younger populations. In addition to these two variables, other somewhat coherent ones are associated such as sexual orientation, left-wing ideology, low income, or belonging to a linguistic minority. These first two clusters respond to issues widely addressed by studies of intersectionality where gender, racialization, sexuality, class, or nationality appear as basic categories of oppression (Crenshaw, 1989; Harris \& Patton, 2019). The fourth brings together categories that have also been highlighted in intersectional studies such as age (over 40), disability and illness (Collins, 2015). The fifth is the least relevant with a combination of identifications around being atheist, agnostic, and indifferent to religion. The implications of these clusters are of great interest as they evidence, from an intersectional analysis perspective, the ways in which structures of domination interact and intersect to influence the specific identity experiences of people from minority groups (Harris \& Patton, 2019; Nash, 2008). Thus, in agreement with cluster 2, a student at a Spanish public university may perceive, within the university, an intersection of oppressions where their gender, sexual orientation, social class, political positioning, and age place them in a differentiated-if not unequal-situation.

In the third cluster, having been ordered according to the greatest similarity between the groups that make them up, an interesting combination emerges as it brings together a series of factors that are not oppressive in themselves and that, at the same time, we could consider hegemonic in Spanish society. On the one hand, Spain is a country that recognizes freedom of religion but is Catholic by tradition. On the other hand, the right-wing ideology in the country is not that of the party that currently governs, but its importance in terms of parties with parliamentary representation in Spanish democracy is clear. Finally, belonging to a high social class would not be a reason for oppression in any context. Hence, we point out the anomaly that this cluster generates and which calls for reflection on the reasons for such perception.

Secondly, from this work, we highlight the importance of conducting research based on the voices of the students themselves, as the protagonists of their experiences of discrimination. In this sense, our work circles back to the proposal from those who point out the importance of starting from the voices of the protagonists in the educational process, especially those of the students (Christensen \& Allison, 2000; Goenechea et al., 2020).

Finally, the empirical evidence provided from this research is considered to be very useful diagnostic material for rethinking what the university can and should do. Based on an inclusive approach from a social justice perspective (Fraser, 1997, 2011, 2012), the results presented in this article allow us to rethink the role of university institutions in three directions: That (1) those who suffer from material deprivation are not limited in their access to higher education, a fact that could affect, to a greater extent, the people whose responses we found in cluster 2, that (2) the diversity of the student body can be freely recognized in the university space, as evidenced by clusters 1, 2, and 5 and that (3) both access and participation in the institution are guaranteed with equal opportunities for all, as especially evidenced by cluster 4, which brings inclusion to the realities of those who have historically experienced social barriers. This all leads to crucial questions regarding redistributive policies that allow people from disadvantaged groups to access and continue in the higher education system. Moreover, it also brings forward questions focused on the recognition and protection of certain especially vulnerable groups through student support systems and, finally, questions regarding the need for university teaching practices to favor social questioning from a critical perspective, as well as the democratic participation of all sectors, especially those historically made invisible, as pointed out by Bowes et al. (2015).

In order for the university, as a fundamental institution of our society, to move beyond a neoliberal role (Díez Gutiérrez, 2011; Nussbaum, 2010) towards inclusion, it is made necessary that we understand the perceptions and experiences of those who experience the university. Although this issue has been addressed in previous studies in the Spanish context (Gairín Sallán \& Suárez, 2016; Goenechea et al., 2020; Padilla-Carmona 
et al., 2017), they have tended to focus on specific collectives. This work has aimed to be an additional contribution to the analysis of this reality in the Spanish context both from the students' perspective and from a commitment to an intersectional approach.

\section{Acknowledgments}

The study we report on in this article was supported by Spain's Ministry of Economy, Industry, and Competitiveness, the State Research Agency, and the European Regional Development Fund (grant number EDU2017-82862-R).

\section{Conflict of Interests}

The authors declare no conflict of interests.

\section{References}

Ahmed, S. (2007). The language of diversity. Ethnic and Racial Studies, 30(2), 235-256.

Ahmed, S. (2012). On being included: Racism and diversity in institutional life. Duke University Press.

Álvarez, J. L., Corpas, R., \& Corpas, C. (2016). Predictores del prejuicio en profesionales que trabajan con colectivos en exclusión social [Predictors of Prejudice in practitioners who work with groups in social exclusion]. Revista de Ciencias Sociales, 22(3), 35-50. https://www.redalyc.org/articulo.oa? id $=28049146004$

Banks, J. A. (Ed.). (2009). Routledge international companion to multicultural education. Routledge.

Barnett, B., \& Felten, P. (Eds.). (2016). Intersectionality in action: A guide for faculty and campus leaders for creating inclusive classrooms and institutions. Stylus Publishing.

Bookchin, M. (2006). The ecology of freedom: The emergence and dissolution of hierarchy. AK Press.

Bowes, L., Evans, J., Nathwani, T., Birkin, G., Boyd, A., Holmes, C., Thomas, L., \& Jones, S. (2015). Understanding progression into higher education for disadvantaged and under-represented groups. Department for Business, Innovation and Skills.

Christensen, P., \& Allison, J. (2000). Research with children: Perspectives and practices. Falmer Press.

Collins, P. H. (2015). Intersectionality's definitional dilemmas. Annual Review of Sociology, 41, 1-20. https:// doi.org/10.1146/annurev-soc-073014-112142

Collins, P. H., \& Bilge, S. (2016). Intersectionality (key concepts). Polity.

Crenshaw, K. W. (1989). Demarginalizing the intersection of race and sex: A black feminist critique of antidiscrimination doctrine. University of Chicago Legal Forum, 1989(1), Article 8. https://chicagounbound. uchicago.edu/cgi/viewcontent.cgi?article $=1052 \&$ context=uclf

Díez Gutiérrez, E. (2011). La macdonalización de la edu- cación superior [The McDonaldization of higher education]. Revista Interuniversitaria de Formación del Profesorado, 72(25/3), 59-76. https://redined.mecd. gob.es/xmlui/bitstream/handle/11162/38073/ 01420123017493. pdf?sequence $=1$ \&isAllowed=y

EHEA Ministerial Conference. (2012). Making the most of our potential: Consolidating the European higher education area. Bucharest Communiqué. https://www. eurashe.eu/library/ehea_2012_bucharestcommunique-pdf

EU (2015). Promoting citizenship and the common values of freedom, tolerance and non-discrimination through education. Publications Office of the EU. https://op.europa.eu/en/publication-detail/-/ publication/ebbab0bb-ef2f-11e5-852901aa75ed71a1

Fraser, N. (1997). Justice interruptus: Critical reflections on the postsocialist condition. Routledge.

Fraser, N. (Ed.). (2011). Dilemas de la justicia en el siglo XXI. Género y globalización [Dilemmas of justice in the 21st century: Gender and globalization]. Universitat de les Illes Balears.

Fraser, N. (2012). Sobre la justicia. Lecciones de Platón, Rawls e Ishiguro [On justice: Lessons from Plato, Rawls and Ishiguro]. New Left Review, 74, 37-46. https://newleftreview.es/issues/74/articles/nancyfraser-sobre-la-justicia.pdf

Gairín Sallán, J., \& Suárez, C. I. (2016). Inclusión y grupos en situación de vulnerabilidad: Orientaciones para repensar el rol de las universidades [Inclusion and vulnerable groups: Guidelines for rethinking the role of universities]. Sinéctica, 46, 1-15. https://sinectica. iteso.mx/index.php/SINECTICA/article/view/625

Gallego-Noche, B. (2019). El buen hacer en educación. Narrativas contrahegemónicas y prácticas inclusivas [The good work of education. Counter-hegemonic narratives and inclusive practices]. Publicaciones UCA.

García-Cano, M., Jiménez-Millán, A., \& Hinojosa-Pareja, E. F. (2021). We're new to this. Diversity agendas in public Spanish universities according to their leaders. The Social Science Journal. Advance online publication. https://doi.org/10.1080/03623319.2020. 1859818

Goenechea, C., Gallego-Noche, B., Amores Fernández, F. J., \& Gómez Ruíz, M. A. (2020). Voces del alumnado gitano sobre su experiencia en la universidad [Gypsy students's voices about their experience in the university]. Profesorado. Revista de Currículum y Formación de Profesorado, 24(2), 462-482. https://doi.org/ 10.30827/profesorado.v24i2.15157

Hanne, A., \& Mainardi, A. I. (2013). Reflexiones sobre la inclusión de grupos en situación de vulnerabilidad en la educación superior [Reflections about inclusion of vulnerable groups in higher education]. Revista de Docencia Universitaria, 11(2), 172-192. https:// doi.org/10.4995/redu.2013.5572

Harris, J., \& Patton, L. (2019). Un/doing intersectional- 
ity through higher education research. The Journal of higher education, 90(3), 347-372. https://doi.org/ 10.1080/00221546.2018.1536936

Hurtado, S., \& Ruiz, A. (2015). Discrimination and bias, underrepresentation, and sense of belonging on campus. Higher Education Research Institute. https://vtechworks.lib.vt.edu/bitstream/handle/ 10919/83064/DiscriminationBiasCampus.pdf? sequence $=1 \&$ is Allowed $=y$

Lall, N. (2011). Estructuras de investigación colaborativa comunidad-universidad: aproximación a su posible impacto [Community-university research partnership structures: Approaches to understanding their impact]. Rizoma freireano-Rhizome freireaInstituto Paulo Freire de España, 9. http://www. rizoma-freireano.org/estructuras-de-investigacioncolaborativa-comunidad-universidad-aproximaciona-su-posible-impacto--nirmala-lall

Lombardi, A., Gelbar, N., Dukes, L. L., III, Kowitt, J., Wei, Y., Madaus, J., Lalor, A. R., \& Faggella-Luby, M. (2016). Higher education and disability: A systematic review of assessment instruments designed for students, faculty, and staff. Journal of Diversity in Higher Education, 11(1), 34-50. http://dx.doi.org/10.1037/ dhe0000027N

Mulcahy, E., Baars, S., Bowen-Viner, K., \& Menzies, L. (2017). The underrepresentation of Gypsy, Roma and traveller pupils in higher education. A report on barriers from early years to secondary and beyond. King's College London. https://www.cfey.org/wp-content/ uploads/2017/07/KINGWIDE_28494_proof3.pdf

Museus, S. D., \& Griffin, K. G. (2011). Mapping the margins in higher education: On the promise of intersectionality frameworks in research and discourse. New Directions for Institutional Research, 151, 5-13. https://doi.org/10.1002/ir.395

Nash, J. C. (2008). Re-thinking intersectionality. Feminist Review, 89, 1-15. https://doi.org/10.1057/fr.2008.4

Nind, M. (2017). The practical wisdom of inclusive research. Qualitative Research, 17(3), 278-288. https://doi.org/10.1177/1468794117708123

Nussbaum, M. (2010). Sin fines de lucro. Por qué la democracia necesita de las humanidades [Not for profit: Why democracy needs the humanities]. Katz Editores.

Padilla-Carmona, C., González-Monteagudo, J., \& SoriaVilchez, A. (2017). Gitanos en la universidad: Un estudio de caso de trayectorias de éxito en la Universidad de Sevilla [Roma in higher education: A case study of successful trajectories at the University of Seville]. Revista de Educación, 377, 187-211. https://doi.org/ 10.4438/1988-592X-RE-2017-377-358

Rawls, J. (1999). A theory of justice. Harvard University Press.

Romero, C., \& Montenegro, M. (2018). Políticas públicas para la gestión de la diversidad sexual y de género: Un análisis interseccional [Public policies in the management of sexual and gender diversity: An intersectional analysis]. Psicoperspectivas, 17(1). https://doi.org/10.5027/psicoperspectivas-Vol17Issue1-fulltext-1211

Spanish Ministry of Universities. (2020). Datos y cifras del sistema universitario español [Facts and Figures of the Spanish university system]. Madrid: author.

UNESCO. (1998). World declaration on higher education for the twenty-first century: Vision and action. UNESCO. https://unesdoc.unesco.org/ark:/ 48223/pf0000141952

UNESCO. (2015). Education 2030: Incheon declaration and framework for action towards inclusive and equitable quality education and lifelong learning for all. UNESCO. https://iite.unesco.org/ publications/education-2030-incheon-declarationframework-action-towards-inclusive-equitablequality-education-lifelong-learning/

West, C., \& Fenstermarker, S. (2010). Haciendo la Diferencia [Making the difference]. In O. Hoffman \& O. Quintero (Eds.), Estudiar el racismo. Textos y herramientas [Studying racism. Texts and tools] (pp. 170-212). AFRODESC and EURESCL. https://goo.gl/bjALkn

\section{About the Authors}
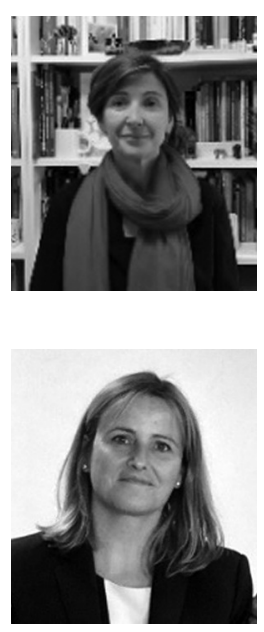

Beatriz Gallego-Noche received her PhD from Seville University and is a Senior Lecturer in the Department of Didactics at the University of Cádiz, Spain. She has participated in projects on inclusion, gender, and teacher training. She has numerous publications in high-impact academic journals and editorials and has been a visiting researcher at prestigious centers in the United Kingdom.

Cristina Goenechea is a Senior Lecturer at the Faculty of Education, University of Cádiz, Spain. Her research focuses on intercultural education, teacher training, and higher education. 


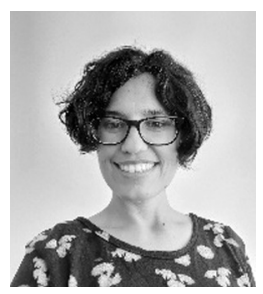

Inmaculada Antolínez-Domínguez received her PhD from Pablo de Olavide University. She is a lecturer in the area of social work in the Department of Labor Law at the University of Cádiz, Spain. She has participated in projects on interculturality, inclusion, gender, migration and human trafficking. She has publications in high-impact academic journals and has been a visiting researcher at centers in the United States, Mexico, Morocco and Italy.

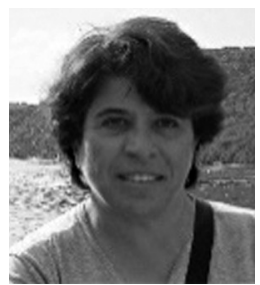

Concepción Valero-Franco holds a degree in Mathematics from the University of Seville and a PhD from the University of Cádiz, Spain, where she currently fulfills the position of Senior Lecturer in the Department of Statistics and Operations Research. Her lines of research and transfer focus on localization, logistics, transport, applied statistics and education, areas in which she has published various research papers in high-impact academic journals. Furthermore, she has collaborated on several national and international projects. 